\title{
Soil Erosion Estimation Using RUSLE Modeling and Geospatial Tool: Case Study of Kathmandu District, Nepal
}

\section{Roshan Dahal ${ }^{1}$}

\begin{abstract}
Revised Universal Soil Loss Equation (RUSLE) model is applied in this study to evaluate the risk of erosion in Kathmandu district. The calculation of erosion requires certain data from various sources available in different formats and scales. Geographic Information System (GIS) was used which allowed considerable time savings in the processing of spatial data, screening the effects of each factor affecting soil erosion. Among various erosion factors, topography, rainfall, soil properties, and soil conservation practices were used for the study. Average soil loss was calculated by multiplying these factors. Final results of soil erosion rates were separated into six classes based on erosion severity, in which $2.18 \%$ of land $(>80 \mathrm{Mg}$ ha-1yr-1), followed by $2.85 \%$ of land ( $40-80 \mathrm{Mg}$ ha-1yr- 1$), 5.56 \%$ of land (20-40 Mg ha-1yr-1), $8.73 \%$ of land (10-20 Mg ha-1yr-1), $10.53 \%$ of land (5-10 Mg ha-1yr-1) and $70.14 \%$ of land (0-5 Mg ha-1yr-1), falls under very severe, severe, very high, moderate and low severity zone respectively. Area having high slope length (LS) factor has high erosion rate. In Dakshinkali, Nagarjun and Budanilkantha area, there is high erosion rate. From the result, spatial distribution of soil erosion across Kathmandu district, can be applied for management and controlling the erosion.
\end{abstract}

Key words: RUSLE, GIS, risk zone, erosion and conservation

Dahal, R. 2020. Soil Erosion Estimation Using RUSLE Modeling and Geospatial Tool:

Case Study of Kathmandu District, Nepal. No. 17: page 118 to 134.

DOI: https://doi.org/10.3126/forestry.v17i0.33627

1 Tribhuvan University, Institute of forestry, Pokhara Campus, Nepal

* Corresponding author, email:dahalroshan321@gmail.com 


\section{Introduction}

Erosion caused by runoff in areas with poor vegetation cover is perhaps the most common process of land degradation because it is irretrievable and is globally widespread causing substantial damage to the landscape (Chadli 2016). Soil erosion, a complex phenomenon, is assessed using various approaches, among which spatial data combination is commonly used. The Revised Universal Soil Loss Equation (RUSLE) model is used in this approach.

Soil and water problems have received considerable attention in recent decades in the global context. About 549-1094 million ha of land are affected by severe problems that impedes the soil resources and agricultural production (Govers et al. 2017). The average rate of erosion throughout the world ranges between 12 and $15 \mathrm{t}$ ha- $-1 \mathrm{yr}-1$, indicating every year $0.90-0.95 \mathrm{~mm}$ of soil loss from the surface (FAO 2015). Around 1.6 billion ha of agricultural land are under degradation, more than 1 billion ha of land come under water erosion prone zone and 550 million under wind erosion susceptible zone (Wawer et al. 2005). Erosion doesn't follow regular pattern buy it is irregularly distributed over the time and space and is difficult to determine how susceptible a particular zone is. It is expected that 5 to $10 \mathrm{ton} / \mathrm{ha} / \mathrm{yr}$ of soil gets eroded from Nepal, meaning that around 2.5 to $5 \mathrm{~m}^{\wedge} 3$ of soil layer is washed out per hectare per year and about 0.2 to $0.5 \mathrm{~mm}$ layer from the top (Prajapati 2014).

In hilly areas, soil erosion is the most serious threat which mostly depends on slope steepness, rainfall intensity, soil texture and its property and land cover, which stimulate high runoff with high sediment load capacity (Nehai et al. 2020). Water erosion is one of the most serious causes of land degradation and about 11 million $\mathrm{km}^{2}$ land area was affected globally (Sato et al. 1994). Soil erosion has degraded the productivity of arable and highly fertile land, which is the direct consequence. Siltation of water bodies is one of the main off-site impact of soil erosion (Govers et al. 2017). Loss of top soil as a result of soil erosion is a challenge for most of the watershed community, landslide in the sloppy area and flood in a flat area (Prasannakumar et al. 2012). Soil erosion by rainfall and surface water flow is generally affected by rainfall erosivity, soil erodibility, topography, surface coverage, and support practices (Ashiagbor et al. 2012). Climatic fluctuation in rainfall and temperature impacts on soil behavior pattern. Higher rainfall intensity directly increases soil erosion, while higher air temperature increases decomposition rate by enhancing the soil organic compound and thus helps to bind the soil particles to minimize the soil erosion ( $\mathrm{Li}$ et al. 2016).

In mountain regions, heavy rainfall and steep slopes coupled with bare land surfaces contribute to severe erosion and degradation (Tamene et al. 2008), which impacts on socio-economy and agricultural production of community (Navas et al. 2004).

In hilly country like Nepal, loss of soil is considerably more from landslides (Fort et al. 2010). Soil erosion in the Himalayan region is endured by landslide, deforestation, overgrazing, shifting cultivation and on the other hand cropping practice in steep 
slope is a practice to reduce erosion (Shrestha et al. 2004). With the advancement in the agricultural production system soil erosion problem has increased (Atreya et al. 2006). Among various soil threats, soil erosion is considered as the main agent around the world (Montanarella et al. 2015). Soil erosion has created very serious impact in the hilly country like Nepal with intense rainfall events in the monsoon season, and unmanaged human influence in the removal of natural vegetation (Chalise et al. 2020). Various researches suggest that in Nepal soil loss ranges from as low as zero in the lowlands to up to $105 \mathrm{Mg} / \mathrm{ha} / \mathrm{yr}$. in upland and reach up to 420 $\mathrm{Mg} / \mathrm{ha} / \mathrm{yr}$. in extreme condition in the shrub land which is due to steep terrain, overgrazing and deforestation (Bajracharya et al. 2009). Similarly soil loss of about 11.17 and $10.74 \mathrm{Mg} / \mathrm{ha} / \mathrm{yr}$. is observed in the Aringale Khola(Chalise et al. 2018) and Sarada river basin (Chalise et al. 2019) in Siwalik region. Soil erosion is most prominent in the context of Nepal mostly in monsoon season, which is aggravated by human activities by the removal of natural vegetation (Chalise et al. 2020). Soil erosion rate and nutrient loss from the soil is highly reported from the degraded forest, grazing land and from sloping agricultural land where maximum tillage operation is carried out (Chalise et al. 2018).

The continuous expansion of cultivated land by reducing the forest area is a major cause of land degradation which executes a greater threat to the fertility of soils (Tolessa et al. 2017). Widespread of agricultural land and forest clearance in a haphazard way is the most common cause of the landscape instability (Lufafa et al. 2003).

RUSLE model was developed based on field data of small land sites or of small catchment in US, having similar climatic, geographic and topographic features. Besides, it helps to estimate soil loss that is caused by splash erosion, rill erosion but not by gully, which is calculated by the help of GIS platform by multiplying various factor that can cause erosion (Efthimiou et al. 2014). RS and GIS have been recognized to be feasible for soil erosion estimation over large area (Bahadur et al. 2012).

RUSLE model was used to measure spatial distribution of soil erosion in Kathmandu. However, RUSLE is appropriate only for the estimation of sheet erosion and rill erosion, not for gully erosion. Despite its limitation, the model combines several parameters to give reasonable estimates of soil erosion. The research may deliver a reference point for the entire Kathmandu district and contribute to soil erosion database.

\section{Materials and Methods}

\section{Study Area}

Kathmandu is the largest city of Nepal, which is very densely populated and situated at an average elevation m 1,400 meters above sea level. 


\section{Study Area Kathmandu District}

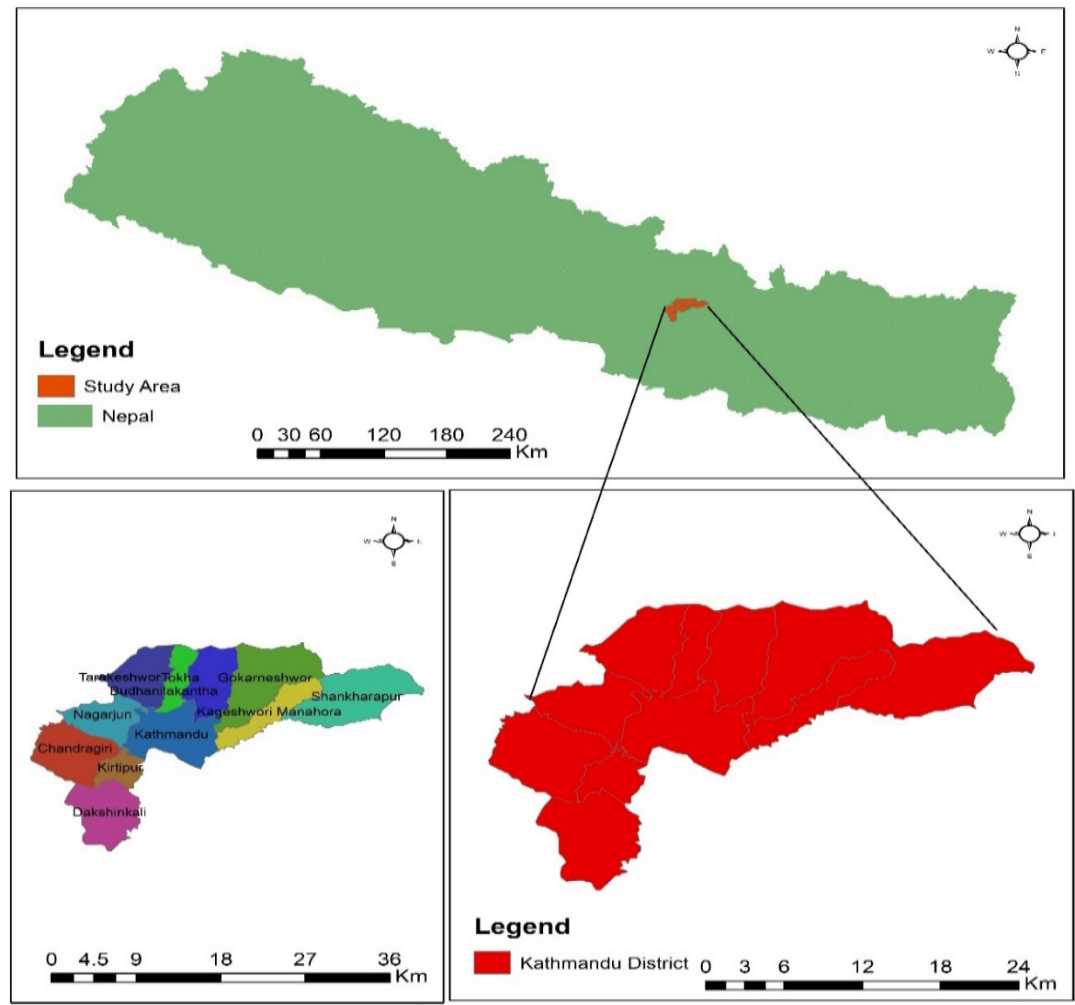

Figure 1: Study Area Map

Average summer temperature varies from 28 to 30 degree Celsius and in winter average temperature is 10.1 degree Celsius. Average annual rainfall is recorded about $1400 \mathrm{~mm}$. Major soil of the Kathmandu district is dominated by fluviallacustrine sediments.

\section{Data Collection}

This study used various datasets developed from different sources. Applied datasets and their relevant sources are listed below.

Table 1: Datasets used for the RUSLE model

\begin{tabular}{|l|l|l|}
\hline Data Sets & Data Source & Factor \\
\hline DEM & https://earthexplorer.usgs.gov/ & LS and P \\
\hline Soil Data & $\begin{array}{l}\text { Soil map prepared by FAOwww.fao.org/geonetwork } \\
\text { (17category of soil based on soil texture) }\end{array}$ & K \\
\hline NDVI from Landsat 8 & $\underline{\text { https://earthexplorer.usgs.gov/ }}$ & C \\
\hline Rainfall Data & $\begin{array}{l}\text { http://chrsdata.eng.uci.edu/ } \\
\text { (Rainfall data for the period of 2008-2018) }\end{array}$ & $\underline{\mathrm{R}}$ \\
\hline
\end{tabular}




\section{Methods}

In this study RUSLE model is used by the application of GIS. Mean soil loss of the study area is calculated by the help of below mention equation.

$\mathrm{A}=[\mathrm{P}]^{*}[\mathrm{~K}]^{*}[\mathrm{LS}]^{*}[\mathrm{R}]^{*}[\mathrm{C}]$

Where $\mathrm{A}=$ Soil loss (Mg/ha/yr.), $\mathrm{R}=$ Rainfall erosivity (MJ mm /ha/yr.), K= Soil erodibility factor $(\mathrm{T} / \mathrm{MJ} / \mathrm{mm}), \mathrm{LS}=$ Slope length steepness factor (Dimensionless), $\mathrm{C}=$ Crop land management factor (Dimensionless), $\mathrm{P}=$ Conservation practice factor (Dimensionless)

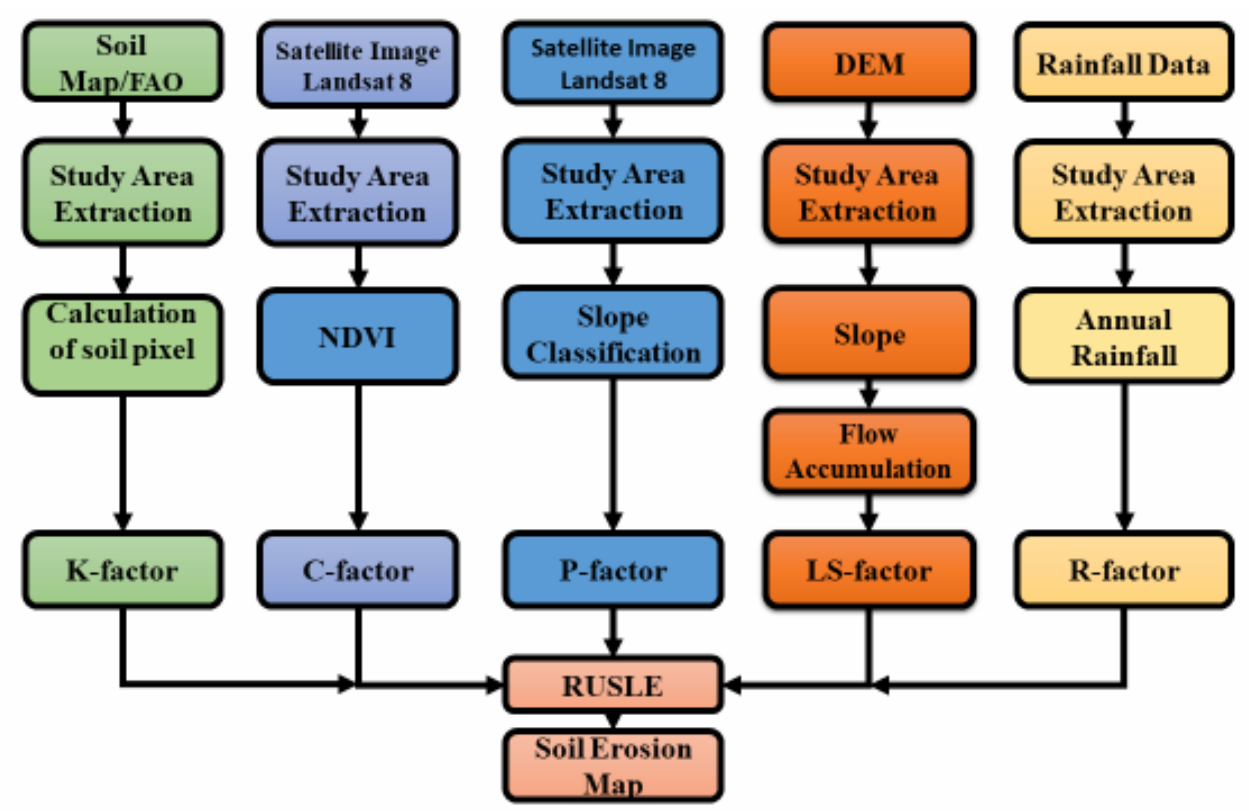

Figure 2: Methodological framework

\section{Various parameters used in RUSLE}

\section{Rainfall Erosivity Factor (R)}

The rainfall erosivity factor $(R)$ is defined as the ability of rain to impact or detach the soil particles based on the rainfall amount. Erosivity used in the RUSLE must recognize the consequence of raindrops that cause impact on soil and clarify the amount of runoff associated with rainfall. In current study, the rainfall data was extracted from Center for Hydrometeorology and Remote Sensing (CHRS) of the overall country and then clip was done to confine with in Kathmandu district. Produced rainfall map symbolizes mean annual precipitation of the Kathmandu district. Given equation is used to calculate R-factor given by (Koirala et al. 2019)

$\mathrm{R}=38.5+0.35 \mathrm{P} \ldots . . \mathrm{Eq} 1$ 
$\mathrm{R}=$ Rainfall erosivity factor

$\mathrm{P}=$ Mean Annual Rainfall (mm)

Soil Erodibility Factor (K)

Measure of vulnerability of soil particles to being detached and transport by rainfall is termed as soil erodibility factor. $\mathrm{K}$ factor is highly affected by soil texture, organic matter contained, soil structure and permeability of the soil. Soil erodibility factor map was prepared from soil map generated by FAO, which was clipped with study area and the pixel that lies in the study area is identified with the help of soil code. By applying the soil map of FAO various soil loss studies have been done in Nepal (Koirala et al. 2019).

Calculations were done using the formulae which given by (Wawer et al. 2005).

Fcsand $=\left[0.2+0.3 \cdot \exp \left(-0.256^{*} \mathrm{Ms}^{*}(1-\mathrm{Msilt} / 100)\right)\right]$

$\mathrm{Fcl}-\mathrm{si}=(\mathrm{Msilt} / \mathrm{Mc}+\mathrm{Msilt})^{\wedge} 0.3$

Forg $\mathrm{C}=\left(1-0.25 \cdot \operatorname{rog} \mathrm{C} / \operatorname{org} \mathrm{C}+\exp \left(3.72-2.95^{*} \mathrm{Org} \mathrm{C}\right)\right)$

Fhsand $=\left(1-0.7-(1 \mathrm{Ms} / 100) /(1-\mathrm{Ms} / 100)+\exp \left(-5.51+22.9^{*}(1-\mathrm{Ms} / 100)\right)\right)$

Kusle $=$ Fcsabd ${ }^{*}$ Fcl-sl ${ }^{*}$ Forgc ${ }^{*}$ Fhiasand....Eq.2

Org C $=\%$ of soil organic carbon (SOC) content

$\mathrm{Ms}=\%$ sand fraction content

Msilt $=\%$ of silt fraction content

$\mathrm{Mc}=\%$ of clay fraction content

\section{Topographic Factor (LS)}

Topographic factor -Slope Length and Steepness (LS) is a combination of slope gradient factor (S) and a slope-length factor (L), which are determined from the DEM. Slope-length factor is a vital parameter in soil erosion modeling and computing transport capacity of surface runoff. An increase in the slope length of area indicates the steepness in which soil loss per unit area increases. The association of soil loss to terrain gradient is influenced by the vegetation coverage and soil particle size. It expresses the effect of topography, specifically hill slope length on erosion.

LS $=\operatorname{Pow}\left[\left(\text { Flowaccum}^{*} \text { cellsize } / 22.1,0.6\right)^{*}\right.$ pow $\left(\sin \left(\right.\right.$ slope $\left.\left.^{*} 0.01745\right) / 0.09,1.3\right]$ (Desalegn et al. 2018) ...eq3 


\section{Support Practice Factor $(P)$}

The P-factor helps in the reduction of the erosion potential of runoff that is influenced by the drainage pattern, runoff velocity and force exerted by flow on the soil surface (Panagoset al. 2015). It expresses the overall effect of supporting conservation practices like contour farming, strip cropping, terracing on soil loss at a particular site, as these practices affect water erosion by altering the flow pattern or direction of surface runoff by reducing the volume and runoff rate (Bruijnzeel 2004).

Among the various types of cropping practices contour cropping and terracing are commonly used to control the erosion of the specific site. Its value ranges from 0 to 1 (Shaikh et al. 2018). Lower the P-factor value, better the practice for controlling soil erosion. Higher P-factor is a fractional amount of erosion that occurs when cultivation practices such as contour cultivation, strip cropping and terracing are used, compared to erosion that would occur without them (Panagos et al. 2015).

In the context of Nepal, terrace farming practices are used on sloping agriculture land, which closely resembles contour farming conservation practice. So we highlight the contour type of farmland as a support practice. Between contouring and terracing, contour farming is very much reliable and easy to construct and very much effective to control run-off and to reduce the erosion from the slope. On the other side, the drawback of terracing is that it is labor-intensive and less productive, and leads to landslides as well (Rey 2004). Also, in many European countries, contour farming is practiced in 5\% steep slopes mainly to reduce the soil erosion (Panagos et al. 2015).

Table 2: $\mathbf{P}$ factor values for slope

\begin{tabular}{|l|l|}
\hline Slope \% & Contouring \\
\hline $0-7$ & 0.55 \\
\hline $7-11.3$ & 0.60 \\
\hline $11.3-17.6$ & 0.80 \\
\hline $17.6-28.7$ & 0.95 \\
\hline$>28.7$ & 1 \\
\hline
\end{tabular}

(Koirala et al. 2019)

\section{Cover Management Factor (C)}

The C-factor accounts for how land cover (for non-croplands) and crops and crop management (for croplands) affect soil erosion as compared to bare fallow areas. Cfactor reflects the effect of cropping and other management practices on erosion rates. Vegetation cover plays an important role in controlling soil erosion risk. Land cover helps to increase interception ratio, infiltration, but reduces rainfall energy. In this study, NDVI was produced with the help of Band 4 and Band 5 image of Landsat 8 and this image was processed in GIS. 
And from that image NDVI is calculated by the formulae (Vatandaşlar et al. 2017).

NDVI=Band5-Band4/Band5+Band4.....eq4

This value ranges from 1 to -1 in which dense forest is indicated by higher value and bare or water bodies is indicated by lower value

C-factor $=0.431-0.805^{*} \mathrm{NDVI}($ Vatandaşlar et al. 2017) $\ldots .$. eq5

C-factor ranges from 0 to approximate 1 , where higher values specify no cover effect and soil loss is higher in this area where vegetation coverage is low, while $C$ value of 0 means a strong cover effect resulting in no erosion. Impact of C-factor on soil erosion is not so much significant when the land use of the area is comprised of high grassland, plantation area. (Atoma et al. 2020).

\section{Results and Discussion}

\section{Results}

\section{Factor Maps}

The results showed that topographic factor (LS) values ranged from 0 to 118.9 , while rainfall erosivity factor (R) values ranged from 266 to $352.45 \mathrm{~mm} / \mathrm{ha} / \mathrm{yr}$. The soil erodibility factor $(\mathrm{K})$ values ranged from 0.16 to 0.54 . The support practice factor $(\mathrm{P})$ values for the entire area ranged from 0.55 to 1 . The cover management factor $(\mathrm{C})$ values ranged from 0.034 to 0.53 .

Table 3: Calculated value of K-factor

\begin{tabular}{|l|l|l|l|l|l|l|l|l|l|}
\hline $\begin{array}{l}\text { Soil unit } \\
\text { symbol }\end{array}$ & $\begin{array}{l}\text { sand \% } \\
\text { topsoil }\end{array}$ & $\begin{array}{l}\text { silt \% } \\
\text { topsoil }\end{array}$ & $\begin{array}{l}\text { clay \% } \\
\text { topsoil }\end{array}$ & $\begin{array}{l}\text { OC \% } \\
\text { topsoil }\end{array}$ & fcsand & Facsi & forgc & fisand & K factor \\
\hline BD 1 & 70 & 20 & 10 & 3 & 0.2 & 0.88 & 0.968 & 0.949 & 0.1629 \\
\hline BD & 32.7 & 30.3 & 37.1 & 3.28 & 0.200 & 2.804 & 0.971 & 0.999 & 0.547 \\
\hline
\end{tabular}

Potential Factor Map and Soil Erosion Map

A potential erosion map of Kathmandu district was produced by multiplying five factors that aggravate the erosion of site with the help of Arc GIS from raster calculator. The results indicate that majority of land, i.e., $70.14 \%$ falls under the low erosion hazard zone $(0-5 \mathrm{Mg} / \mathrm{ha} / \mathrm{yr}$.), $2.18 \%$ of the land falls under very severe erosion risk zone ( $>80 \mathrm{Mg} / \mathrm{ha} / \mathrm{yr})$ and $26.67 \%$ of land under moderately, high, very high, and severe risk zones which need conservation measures to reduce the risk of soil erosion. High erosion rate is seen in steep slope with barren land which is followed by agricultural and forest land. Area of various severity zones was calculated using the zonal statistical table by the weighted mean method. 


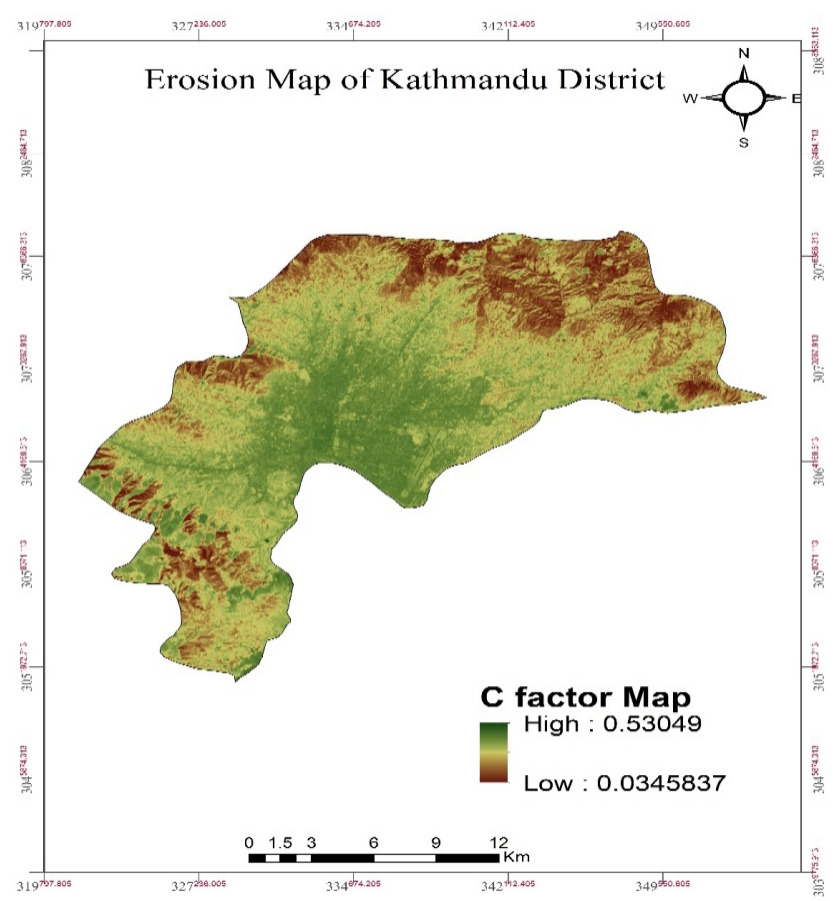

Figure 3: C-factor map of Kathmandu district

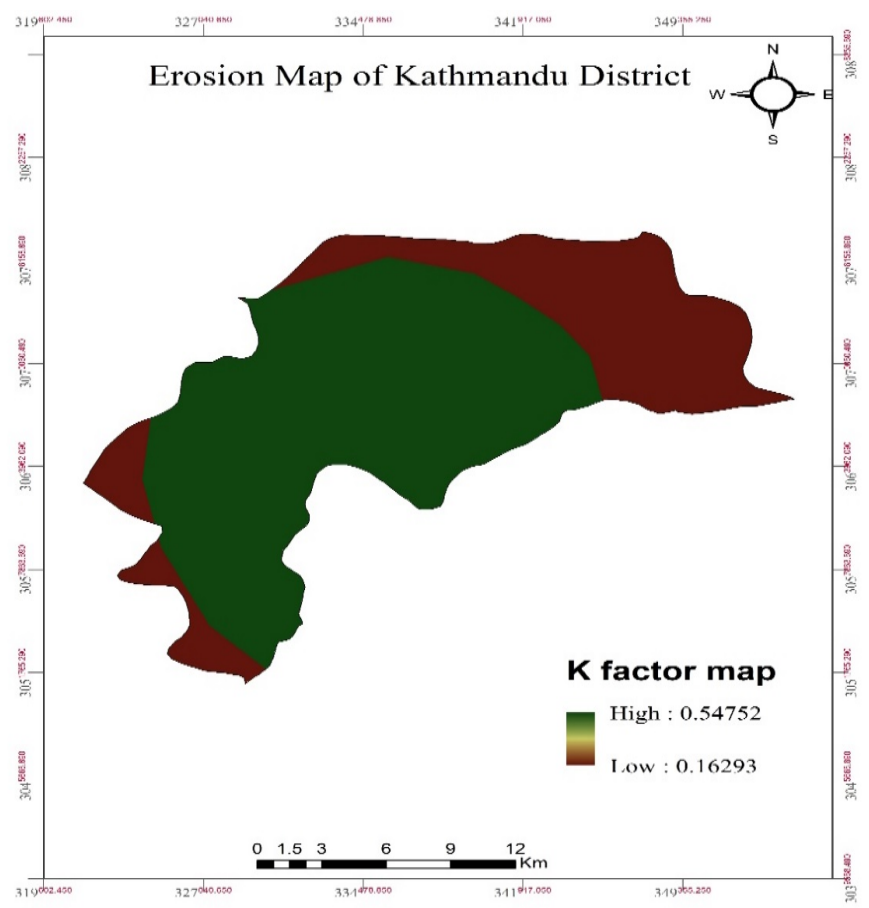

Figure 4: K-factor map of Kathmandu district 


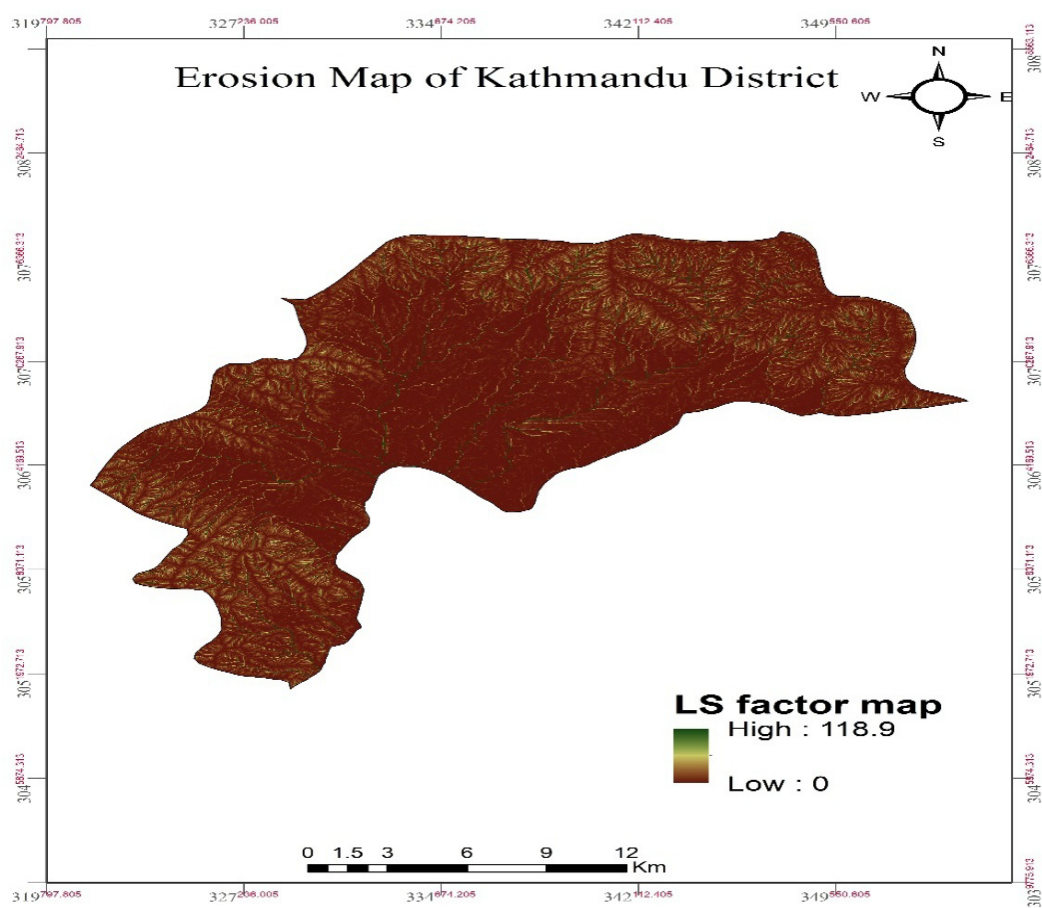

Figure 5: LS factor map of Kathmandu district

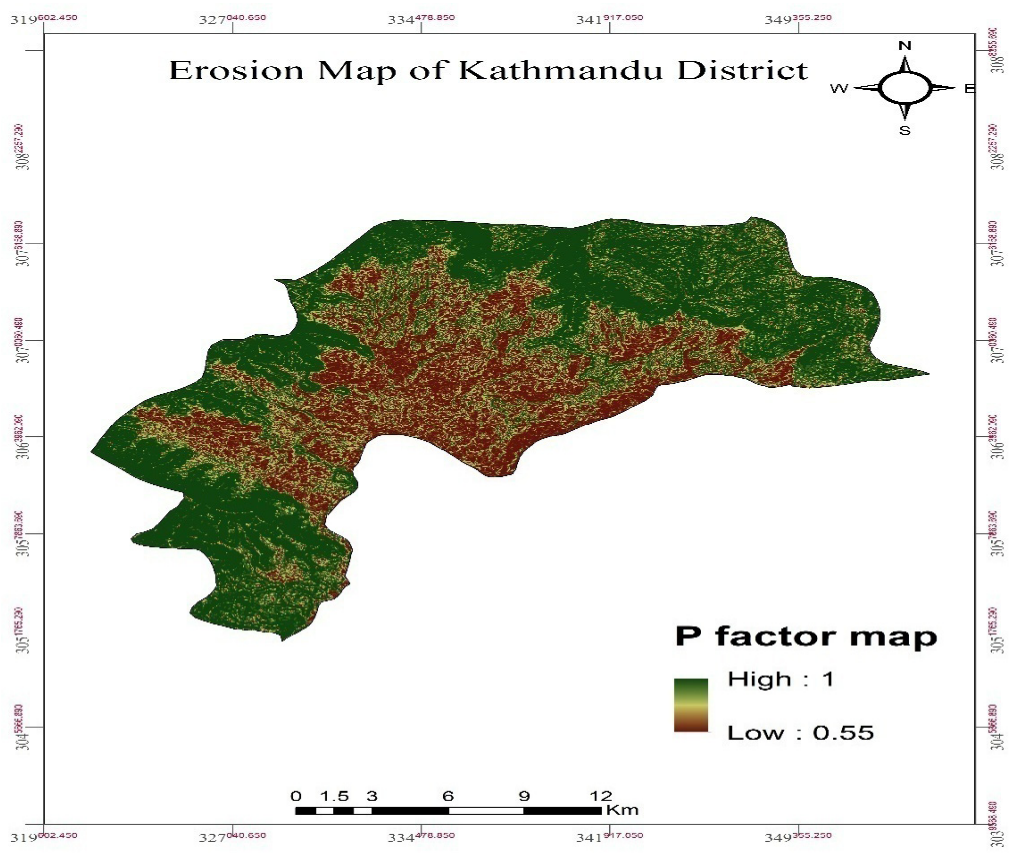

Figure 6: P-factor map of Kathmandu district 


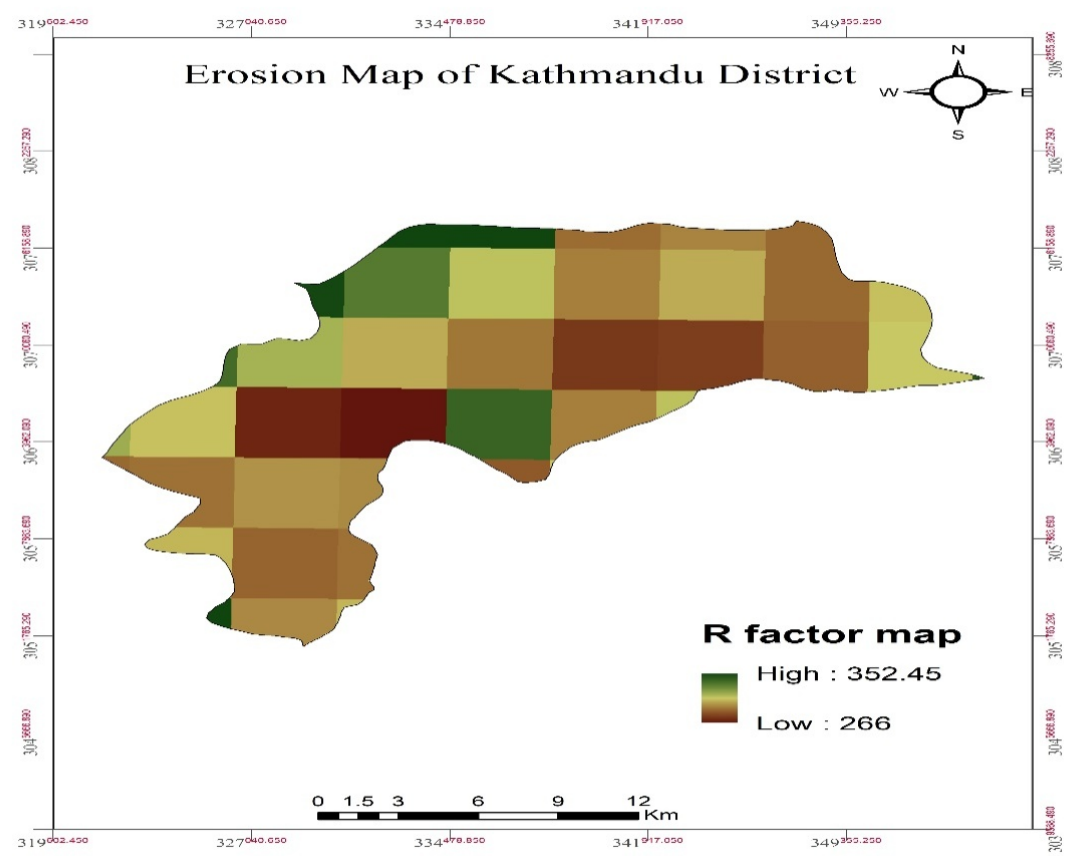

Figure 7: R-factor map of Kathmandu district

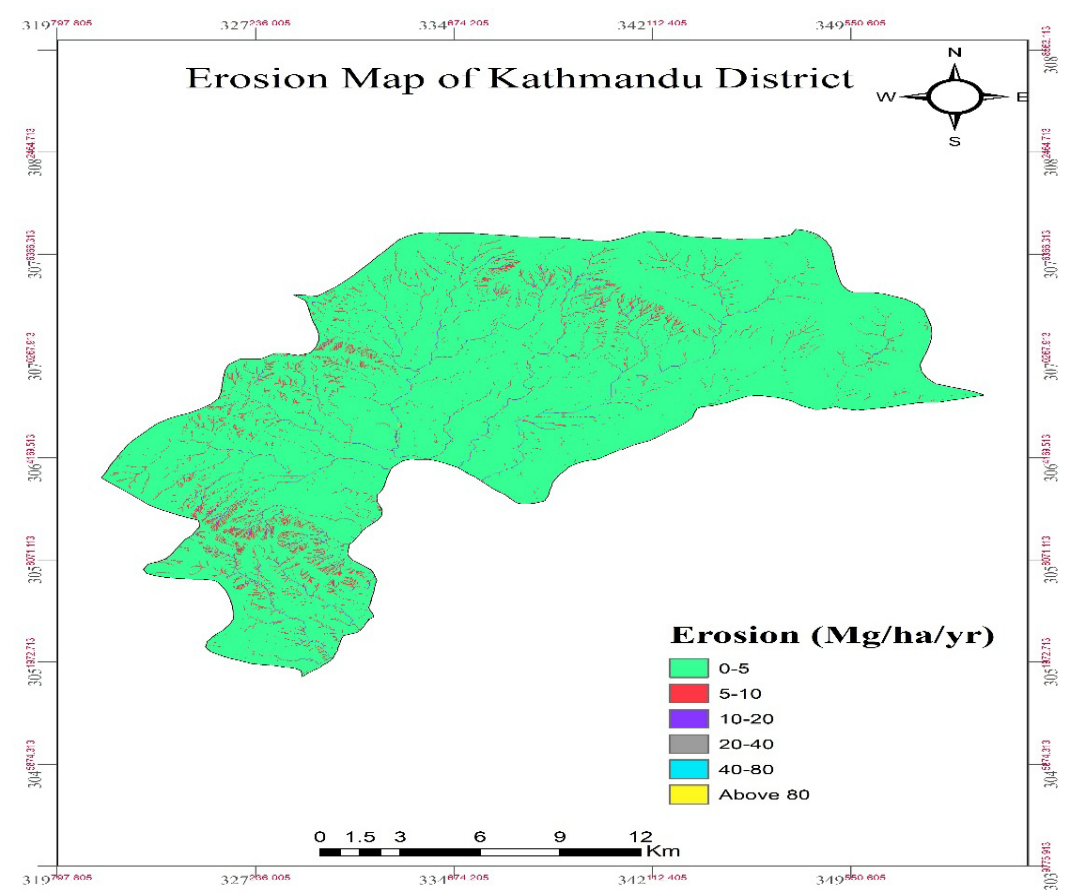

Figure 8: Erosion map of Kathmandu district 
Table 4: Potential soil erosion of Kathmandu district

\begin{tabular}{|l|l|l|l|l|}
\hline Class & $\begin{array}{l}\text { Rate of Erosion } \\
\mathbf{( M g} / \mathbf{h a} / \mathbf{y r} .)\end{array}$ & Area (Sq.km) & \% of Area & Severity \\
\hline 1 & $0-5$ & 266.41 & $70.14 \%$ & Low \\
\hline 2 & $5-10$ & 39.99 & $10.53 \%$ & Moderate \\
\hline 3 & $10-20$ & 33.15 & $8.73 \%$ & High \\
\hline 4 & $20-40$ & 21.08 & $5.56 \%$ & Very High \\
\hline 5 & $40-80$ & 10.85 & $2.85 \%$ & Severe \\
\hline 6 & Above 80 & 8.29 & $2.18 \%$ & Very Severe \\
\hline
\end{tabular}

\section{Discussion}

RUSLE modeling helps to develop a spatial assessment of erosion vulnerability of specified location with the help of remotely-sensed data. A similar model has been used, for the area having similar geographical and topographical features (Devatha et al. 2015).

With the increase in slope length and steepness along with an increase in rainfall, rate of erosion also speeds up (Assouline et al. 2006). In Trans-Himalayan zone, rainfall erosivity value is very low in comparison with other regions in which there is very less mean annual rainfall which is directly linked with the amount of rainfall energy. Value of $C$ factor differ from place to place and is influenced by land use type, canopy and surface cover as well as soil moisture condition (Koirala et al. 2019).

Study conducted in India shows that by increasing agricultural and decreasing forest category, the gross amount of erosion increased by 14,673.5 t/yr. which was more than $3.1 \%$ (Ganasri et al. 2016). Increase in soil loss was mainly due to increases in agricultural activities like ploughing, and tillage operation (Ganasri et al. 2016). In undisturbed forestland, erosion rate is usually very low. Deforestation, unmanaged mining, wildfires, and compacted soil from animal grazing increase soil erosion risk, which supports our finding that agricultural land and highly dense forest have low erosion rate than the area that is bare and highly disturbed (Karamage et al. 2016). Degradation of rangeland compacts the soil, which increases the surface runoff and decreases the soil moisture content in all soil layer, which reduces the vegetation cover (Al-Seekh et al. 2009).

P-factor plays an impressive role in reducing erosion from the area that has high slope length, by application of appropriated cropping technique. Support practices such as contour farming and terracing can reduce soil erosion by maintaining the minimum tillage technique. Increase in amount of grass margin, maintenance of stone wall and the application of contour farming can further reduce erosion on arable lands (Panagos et al. 2015). Steep slope with intense rainfall leads to high 
runoff which is the main reason of erosion (Devatha et al. 2015). Vegetation distributions of an area is indicated by $\mathrm{C}$ factor. It indicates the protecting effect of vegetation which reduces and dissipates the kinetic energy of precipitation to reduce the runoff pattern to minimize the erosion. Low value of $\mathrm{C}$-factor indicates the area of dense vegetative coverage area and low value indicates the area of low vegetation coverage (Panagos et al. 2015).

In Dolakha district, GIS and RUSLE model were applied to estimate erosion based on severity class, in which around $5.01 \%$ of the land area was under extreme risk, while around $70 \%$ of the area was in low-risk zone (Thapa, n.d.). Areas having steep slope along with high intensity of rainfall are most vulnerable to soil erosion. The projected outcome can provide a basis for conservation of high risk prone area and planning effective measure to minimize the upcoming disaster by decision-makers.

Karmage et al. (2016) states that in Rowanda terracing and contour farming are adopted as the best conservation practice among others for reducing soil erosion in cropland areas up to about $23 \%$. They recommend increasing vegetation and control of human activities and soil compaction by domestic animals during grazing. High rate of soil erosion in Indonesia has occurred because of inappropriate agricultural practices on very steep slopes. Now as a preventive measure no-tillage system has started for reducing soil erosion (Kassam et al. 2012).

Under mechanical method in China, terracing and contour farming practice is increasing as a preventive measure to control erosion (Nichols et al. 1938).

\section{Conclusion}

For the estimation of potential soil erosion in the Kathmandu district, the RUSLE model was used, in which five factors were determined with the help of GIS and various factors like mean annual rainfall of 10 years data, soil data, DEM, land use of specific location were used. The soil erosion rates of Kathmandu district were classified into six various classes based on rate of erosion that is found in specific location in which $2.18 \%$ of the land fall under extreme risk $(>80 \mathrm{Mg} / \mathrm{ha} / \mathrm{yr}-1)$, $70.14 \%$ of the land area was in the low risk zone (0-5 Mg/hayr- 1$)$, about $10.53 \%$ (5$10 \mathrm{Mg} / \mathrm{hayr}-1)$, 8.73\% (10-20 Mg/ha/yr-1), 5.56\% (20-40 Mg/ha/yr-1) and 2.85\% (40$80 \mathrm{Mg} / \mathrm{ha} / \mathrm{yr}-1)$ of land fall under moderate, high, very high and severe zone. In Dakshinkali, Nagarjun and Budanilkantha areas, there is high erosion. The results showed that the areas with steep slope, high intensity of rainfall, bare land are most prone to erosion. The projected risk zone can guide for the conservation and proper utilization of land. Regions which are very prone to soil erosion demand high attention to apply appropriate measure to control it. On the whole this model provides a projection of erosion mapping base on using remotely sensed data and GIS platform with the outcome of vulnerable zone. Conservation measures like terracing, contouring, and grassed waterways can be used frequently. At the same time, mulching and mix cropping in multistory canopy structure with perennial crops give best result to control erosion form degraded and agricultural land. 


\section{Acknowledgement}

I would like give special thanks to Pratima Dhungana who assisted me throughout the research and without whom the completion of the study would not have been possible. Special thanks go to Mr. Jeetendra Gautam, Assistant Professor, Agriculture and Forestry University, who helped me with GIS mapping.

\section{Literature Cited}

Al-Seekh, S. H., and A.G. Mohammad. 2009. The effect of water harvesting techniques on runoff, sedimentation, and soil properties. Environmental Management, 44(1), 37-45. https:/ / doi.org/10.1007/s00267-009-9310-z

Ashiagbor, G., E.K. Forkuo, P. Laari, and R. Aabeyir. 2012. Modeling Soil Erosion Using Rusle and Gis Tools. International Journal of Remote Sensing $\mathcal{E}$ Geoscience (IJRSG), 2(January 2016), 7-17.

Assouline, S., and M. Ben-Hur. 2006. Effects of rainfall intensity and slope gradient on the dynamics of interrill erosion during soil surface sealing. Catena, 66(3), 211-220. https://doi.org/10.1016/j.catena.2006.02.005

Atoma, H., K.V. Suryabhagavan and M. Balakrishnan2020. Soil erosion assessment using RUSLE model and GIS in Huluka watershed, Central Ethiopia. Sustainable Water Resources Management, 6(1). https://doi.org/10.1007/s40899-020-00365-z

Atreya, K., S. Sharma, R.M. Bajracharya, and N.P. Rajbhandari. 2006. Applications of reduced tillage in hills of central Nepal. Soil and Tillage Research, 88(1-2), 1629. https://doi.org/10.1016/j.still.2005.04.003

Bajracharya, A. R., S.R. Bajracharya, A.B. Shrestha, and S.B. Maharjan. 2018. Climate change impact assessment on the hydrological regime of the Kaligandaki Basin, Nepal. Science of the Total Environment, 625(January), 837-848. https:/ / doi.org/10.1016/j.scitotenv.2017.12.332

Bruijnzeel, L. A. 2004. Hydrological functions of tropical forests: Not seeing the soil for the trees? In Agriculture, Ecosystems and Environment (Vol. 104). https://doi.org/10.1016/j.agee.2004.01.015

chadli, K. 2016. Estimation of soil loss using RUSLE model for Sebou watershed (Morocco). Modeling Earth Systems and Environment, 2(2), 1-10. https://doi.org/10.1007/s40808-016-0105-y

Chalise, D., and L. Kumar. 2020. Land use change affects water erosion in the Nepal Himalayas. PLoS ONE, 15(4). https:/ / doi.org/10.1371/journal.pone.0231692

Chalise, D., L. Kumar, R. Sharma, and P. Kristiansen. 2020. Assessing the impacts of tillage and mulch on soil erosion and corn yield. Agronomy, 10(1), 1-13. https://doi.org/10.3390/agronomy10010063 
Chalise, D., L. Kumar, C.P. Shriwastav and S. Lamichhane. 2018. Spatial assessment of soil erosion in a hilly watershed of Western Nepal. Environmental Earth Sciences, 77(19), 0. https:/ / doi.org/10.1007/s12665-018-7842-3

Chalise, D., L. Kumar, V. Spalevic, and G. Skataric. 2019. Estimation of sediment yield and maximum outflow using the IntErO model in the Sarada River Basin of Nepal. Water (Switzerland), 11(5). https://doi.org/10.3390/w11050952

Desalegn, A., A. Tezera, and F. Tesfay. 2018. Developing GIS-Based Soil Erosion Map Using RUSLE of Andit Tid Watershed, Central Highlands of Ethiopia. Journal of Scientific Research and Reports, 19(1), 1-13. https://doi.org/10.9734/jsrr/2018/40841

Devatha, C. P., V. Deshpande and M.S. Renukaprasad. 2015. Estimation of Soil loss Using USLE Model for Kulhan Watershed, Chattisgarh- A Case Study. Aquatic Procedia, 4(Icwrcoe), 1429-1436. https://doi.org/10.1016/j.aqpro.2015.02.185

Efthimiou, N., E. Lykoudi, and C. Karavitis. 2014. Soil erosion assessment using the RUSLE model and GIS. European Water, 47(January), 15-30.

FAO. 2015. World' s Soil Resources. Status of the World's Soil Resources, 650. https://doi.org/978-92-5-109004-6

Ganasri, B. P., and H. Ramesh2016. Assessment of soil erosion by RUSLE model using remote sensing and GIS - A case study of Nethravathi Basin. Geoscience Frontiers, 7(6), 953-961. https:/ / doi.org/10.1016/j.gsf.2015.10.007

Govers, G., R. Merckx, B. Van Wesemael, and K. Van Oost. 2017. Soil conservation in the 21st century: Why we need smart agricultural intensification. Soil, 3(1), 45-59. https://doi.org/10.5194/soil-3-45-2017

Karamage, F., H. Shao, X. Chen, F. Ndayisaba, L. Nahayo, A. Kayiranga, et. al. 2016. Deforestation effects on soil erosion in the Lake Kivu Basin, D.R. CongoRwanda. Forests, 7(11), 1-17. https://doi.org/10.3390/f7110281

Koirala, P., S. Thakuri, S. Joshi, and R. Chauhan. 2019. Estimation of Soil Erosion in Nepal using a RUSLE modeling and geospatial tool. Geosciences (Switzerland), 9(4). https:/ / doi.org/10.3390/geosciences9040147

Krishna Bahadur, K. C. 2012. Spatio-temporal patterns of agricultural expansion and its effect on watershed degradation: A case from the mountains of Nepal. Environmental Earth Sciences, 65(7), 2063-2077. https://doi.org/10.1007/s12665-011-1186-6

Li, Z., and H. Fang. 2016. Impacts of climate change on water erosion: A review. Earth-Science Reviews, 163, 94-117. https://doi.org/10.1016/j.earscirev.2016.10.004

Lufafa, A., M. M. Tenywa, M. Isabirye, M. J. G. Majaliwa, and P.L. Woomer. 2003. Prediction of soil erosion in a Lake Victoria basin catchment using a GIS- 
based Universal Soil Loss model. Agricultural Systems, 76(3), 883-894. https://doi.org/10.1016/S0308-521X(02)00012-4

Montanarella, L., D.J. Pennock, N.J. McKenzie, M. Badraoui, V. Chude, I. Baptista, et al. World's soils are under threat. SOIL Discussions, 2(2), 1263-1272. https://doi.org/10.5194/soild-2-1263-2015

Navas, A., B. Valero Garcés, and J. Machín. 2004. Research Note: $<$ br $>$ An approach to integrated assessement of reservoir siltation: the Joaquín Costa reservoir as a case study. Hydrology and Earth System Sciences, 8(6), 1193-1199. https://doi.org/10.5194/hess-8-1193-2004

Nehai, S. A., M. S. Guettouche, and D. Saadoud. 2020. Regional modeling of soil sensitivity to water erosion in JIJEL region (Algeria) using MCA and GIS. Applied Geomatics. https://doi.org/10.1007/s12518-020-00316-5

Panagos, P., P. Borrelli, K. Meusburger, C. Alewell, E. Lugato, and L. Montanarella. 2015. Estimating the soil erosion cover-management factor at the European scale. Land Use Policy, 48, 38-50. https://doi.org/10.1016/j.landusepol.2015.05.021

Panagos, P., P. Borrelli, K. Meusburger, E.H. van der Zanden, J. Poesen, and C. Alewell. 2015. Modelling the effect of support practices (P-factor) on the reduction of soil erosion by water at European scale. Environmental Science and Policy, 51, 23-34. https://doi.org/10.1016/j.envsci.2015.03.012

Prajapati, E. R. N. 2014. Estimation of Soil Erosion By Using USLE Estimation of Soil Erosion by using USLE. (June).

Prasannakumar, V., H. Vijith, S. Abinod, and N. Geetha. 2012. Estimation of soil erosion risk within a small mountainous sub-watershed in Kerala, India, using Revised Universal Soil Loss Equation (RUSLE) and geo-information technology. Geoscience Frontiers, 3(2), 209-215. https://doi.org/10.1016/j.gsf.2011.11.003

Rey, L. D. 2004. A review of the effect of terracing on erosion. Soil Conservation And Protection for Europe, (January 2004), 97-108. Retrieved from http://139.191.1.96/projects/scape/transf/Dorren_Rey.pdf

Sato, Y., M. Ikeda, and O. Yamashita. 1994) Neurosecretory cells expressing the gene for common precursor for diapause hormone and pheromone biosynthesisactivating neuropeptide in the suboesophageal ganglion of the silkworm, Bombyx mori. General and Comparative Endocrinology, 96(1), 27-36. https://doi.org/10.1006/gcen.1994.1156

Shaikh, M. S., and R.V. Shetkar. 2018. Soil Erosion Estimation Modelling by Revised Universal Soil Loss Equation and Soil and Water Assessment Tool on Geographic Information System Platform. (October). 
Shrestha, D. P., J. A. Zinck, and E. Van Ranst. 2004. Modelling land degradation in the Nepalese Himalaya. Catena, 57(2), 135-156. https://doi.org/10.1016/j.catena.2003.11.003

Tamene, L., and P. L. G. Vlek. 2008. Soil erosion studies in Northern Ethiopia. Land Use and Soil Resources, 73-100. https://doi.org/10.1007/978-1-4020-6778-5_5

Thapa, P. 2020. Spatial Estimation of Soil Erosion Using RUSLE Modeling : A case study of Dolakha District, Nepal.1-13.

Tolessa, T., F. Senbeta, and F. Kidane. 2017. The impact of land use/land cover change on ecosystem services in the central highlands of Ethiopia. Ecosystem Services, 23(November 2016), 47-54. https://doi.org/10.1016/j.ecoser.2016.11.010

Vatandaşlar, C., and M. Yavuz. 2017. Modeling cover management factor of RUSLE using very high-resolution satellite imagery in a semiarid watershed. Environmental Earth Sciences, 76(2). https://doi.org/10.1007/s12665-0176388-0

Wawer, R., E. Nowocieñ, and B. Podolski B. 2005. Real_and_Calc_Erodibility. 14(5), 655-658. Retrieved from http://www.6csnfn.pjoes.com/pdf/14.5/655658.pdf 